\title{
HISTOCHEMICAL LOCALIZATION OF HYDROXYSTEROID DEHYDROGENASES IN THE MAXILLARY GLANDS OF PIGS
}

\author{
P. F. FLOOD \\ Department of Veterinary Anatomy, University of Bristol
}

(Received 17th Fuly 1972)

The maxillary salivary gland of the boar is known (Patterson, 1968) to be rich in androstenol ( $3 \alpha$-hydroxy- $5 \alpha$-androst-16-ene) and to be capable of converting pregnenolone to $3 \beta$-hydroxyandrosta-5,16-diene (Katkov \& Gower, 1969). In addition, it has been suggested by Patterson (1968) that the maxillary gland may be a site of origin of androstenone ( $5 \alpha$-androst-16-ene-3-one), but this compound is also present in testicular venous plasma (Gower, Harrison \& Heap, 1970). Androstenone has pheromonal properties in the pig (Melrose, Reed \& Patterson, 1971) and is apparently released during the profuse salivation which occurs in the male at the time of copulation. In an attempt to elucidate the site and nature of steroid metabolism in the maxillary gland, its hydroxysteroid dehydrogenases were studied histochemically. Hydroxysteroid dehydrogenases acting at the $11 \beta$ position have already been reported in the ducts of porcine salivary glands (Ferguson, Glen \& Mason, 1970): the present study is concerned with those acting at positions 3 and 17.

Maxillary and parotid glands were obtained from one male and one female fetus at 56,73,78 and 84 days' gestation, one male and one female piglet at 5 days of age, four gilts and four castrate males of about $80 \mathrm{~kg}$ live weight, six entire males with well-developed sex odour ranging from 80 to $100 \mathrm{~kg}$ live weight and three pregnant sows aged 4 to 5 years. In addition, maxillary glands alone were obtained from four 100-day-old gilts. The tissues were removed from the carcass at slaughter and frozen by vigorous agitation in liquid nitrogen.

The histochemical demonstration of hydroxysteroid dehydrogenases has been fully described by Baillie, Ferguson \& Hart (1966). In the present study, cryostat sections were cut at $10 \mu \mathrm{m}$, mounted on coverslips and incubated in medium containing substrate $(0.5 \mathrm{mmol} / \mathrm{litre})$, nicotinamide-adenine dinucleotide $(\mathrm{NAD}-0.25 \mathrm{mg} / \mathrm{ml})$ and nitro blue tetrazolium $(0.1 \mathrm{mg} / \mathrm{ml})$ in a phosphate buffer $(0.5 \mathrm{~mol} /$ litre $)$ adjusted to $\mathrm{pH} 7$. The steroid solvent was dimethylformamide which proved satisfactory for all substrates other than androstenol which formed a heavy precipitate on addition to the aqueous medium. Control sections were incubated in medium lacking substrate and in medium lacking both substrate and NAD but containing $\mathrm{NADH}_{2}(0.25 \mathrm{mg} / \mathrm{ml})$. As an additional control, bovine and ovine maxillary gland tissue from adult females and castrate males was incubated in all media. The substrates used were testosterone and oestradiol-17 $\beta$ (for $17 \beta$-hydroxysteroid dehydrogenases) dehydroepiandro- 
sterone $\left(\Delta^{5}-3 \beta\right)$, androsterone and androstenol $(5 \alpha-3 \alpha), 3 \alpha$-hydroxy- $5 \beta$-androstan-17-one $(5 \beta-3 \alpha), 3 \beta$-hydroxy-5 $\alpha$-androstan-17-one $(5 \alpha-3 \beta)$ and $3 \beta$-hydroxy$5 \beta$-androstan-17-one $(5 \beta-3 \beta)$. An incubation time of $1 \mathrm{hr}$ at $37^{\circ} \mathrm{C}$ was used with all substrates other than androstenol which was incubated for $2 \mathrm{hr}$. The substrate-free controls were also incubated for $2 \mathrm{hr}$.

Slight histochemical activity was present in a few ducts in the maxillary glands of the 78-and 84-day fetuses when $5 \alpha-3 \alpha$ and $3 \beta$-hydroxy substrates were used (P1. 1, Fig. 1); by 5 days post partum, activity was well developed in both the ducts and the acinar tissue (PI. 1, Fig. 2). Similar strong reactions were seen in the 100-day-old gilts (Pl. 1, Fig. 3) and in all the older pigs. Activity was most intense in the excretory and striated ducts, less intense in the intercalated ducts and slight in the serous demilunes (Pl. 1, Figs 3 to 5). The mucous cells showed no activity. There was a clear difference between the distribution of pigment following incubation with $5 \alpha-3 \alpha$ and $3 \beta$-hydroxy substrates. Activity in the ducts was particularly intense after the use of $3 \beta$ substrates and that in the serous demilunes relatively slight (Pl. 1, Fig. 5) and the section appeared finely stippled to the naked eye; $5 \alpha-3 \alpha$ substrates also gave maximal activity in the ducts but the contrast between these and the remainder of the gland was much less marked (Pl. 1, Fig. 6), and macroscopically the sections appeared uniform. Though activity was present in the parotid glands of pigs of $80 \mathrm{~kg}$ and over, the level of activity was very much less than that seen in the maxillary glands. However, as in the maxillary glands, the deposition of pigment was usually greatest in the ducts, though even here the rate of substrate oxidation was little above the minimum detectable by the method. Though the parotid and maxillary glands showed markedly different characteristics, there were no apparent differences in the enzyme distributions of boars, sows, gilts and hogs (Pl. 1, Figs 4 and 5). The intense $\Delta^{5}-3 \beta$ hydroxysteroid dehydrogenase activity found in the serous cells of the mature boar by W. D. Booth, H. M. Dott and M. F. Hay (personal communication) was not seen: this is almost certainly attributable to the relative immaturity of the boars used in the present study.

No histochemical activity was detected in the substrate-free controls though strong reactions always followed incubation with $\mathrm{NADH}_{2}$ indicating adequate levels of the diaphorase linking the oxidation of $\mathrm{NADH}_{2}$ to the reduction of nitro blue tetrazolium. No activity was found in any of the glands taken from 56- and 73-day fetuses or in parotid glands taken from any of the fetuses or the 5-day-old piglets. Likewise, no activity was found in the ruminant salivary glands examined and no reactions were obtained from any of the tissues following incubation with $17 \beta$-hydroxy substrates and $3 \alpha$-hydroxy- $5 \beta$-androstan17-one.

These results suggest that the maxillary gland of the pig can be an important site of steroid metabolism and they are therefore in agreement with those of Patterson (1968) and Katkov \& Gower (1969). The fact that only minimal activity was observed in parotid tissue is consistent with the finding that androstenone levels in the parotid gland differ little from those in adipose tissue (Claus, Hoffman \& Karg, 1971) and with the absence of sex odour in the parotid glands of all but the most heavily tainted boar carcasses (Patterson, 1968). The results show that steroid metabolism is most likely to occur in the 
PLATE 1
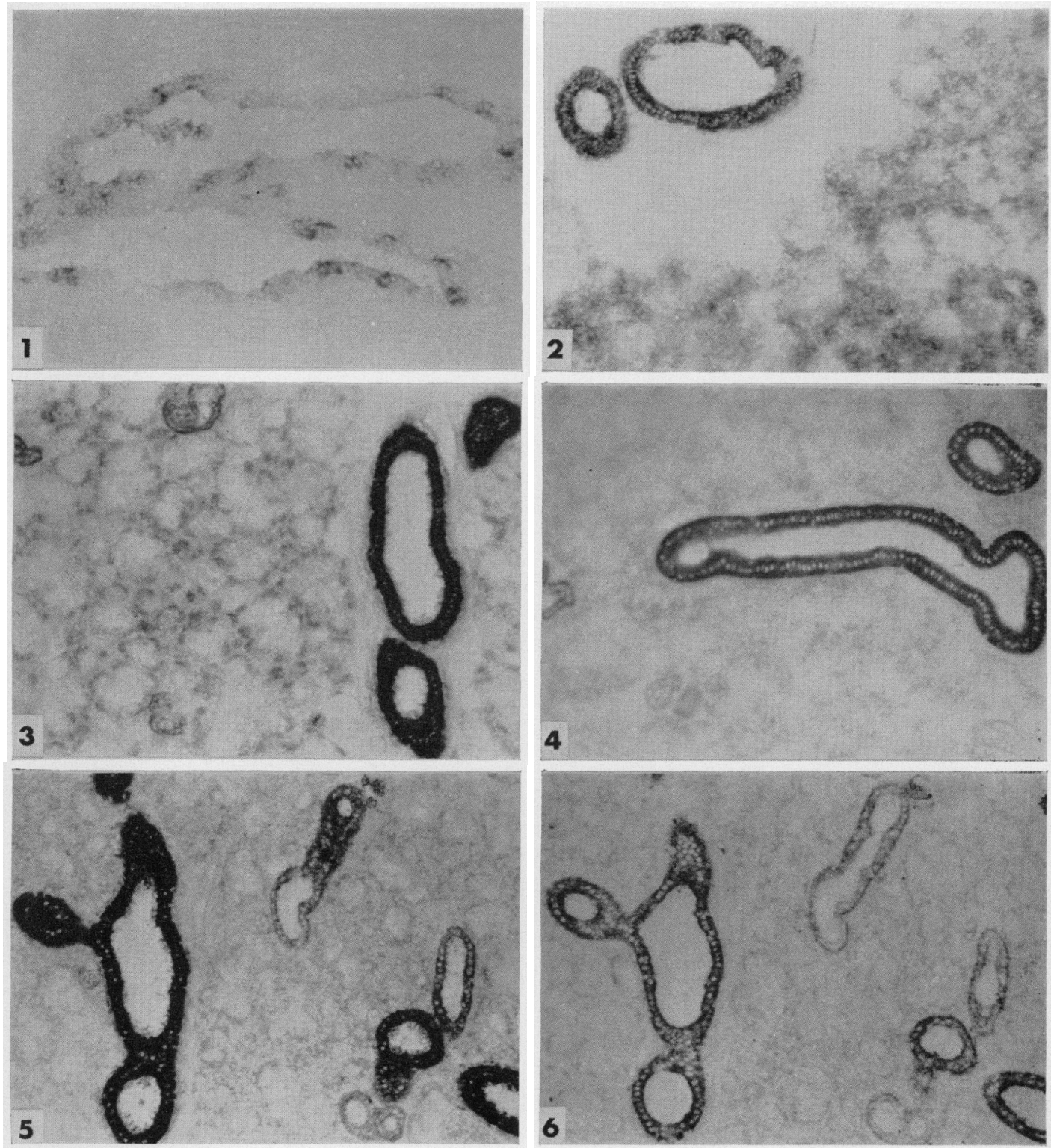

Fic. 1. The maxillary gland of an 84-day pig fetus showing that $5 \beta$-3 $\beta$-hydroxysteroid dehydrogenase activity is confined to a few cells of the excretory duct epithelium. $\times 9 \bar{c}$.

Fic, 2. The ducts and acinar tissue of the maxillary gland of a 5-day-old gilt showing the distribution of $5 \beta$-3 $\beta$-hydroxysteroid dehydrogenase activity. $\times 95$.

Frg. 3. The maxillary gland of a 100-day-old gilt showing that moderate $5 \beta-3 \beta$-hydroxysteroid dehydrogenase activity is present in the serous demilunes. There is intense activity in the striated ducts on the right. $\times 95$.

Fic. 4 . The maxillary gland of a castrate male showing $5 \beta-3-\beta$-hydroxysteroid dehydrogenase activity. $\times 95$.

FIc; 5 . The maxillary gland of a boar showing $\Delta^{5}-3 \beta$-hydroxysteroid dehydrogenase activity. $\times 95$.

FI(;. 6. The maxillary gland of a boar showing $5 \alpha-3 \alpha$-hydroxysteroid dehydrogenase activity. Deposition of pigment in the striated ducts is significantly less than that seen in Fig. 5 which shows an adjacent section. $\times 95$. 
ducts but may also occur to a limited extent in the serous demilunes. Further, they indicate the possibility of hydroxysteroid dehydrogenase secretion in the saliva. The fact that $3 \alpha$ and $3 \beta$ substrates gave different pigment distributions suggests that at least two enzymes are involved, one utilizing $3 \beta$-hydroxy substrates having $5 \alpha, 5 \beta$ or $\Delta^{5}$ configurations and one utilizing $3 \alpha$-hydroxy substrates with the $5 \alpha$ configuration but not those with the $5 \beta$ form. The ability of the $3 \alpha$ enzyme to utilize androstenol suggests that it may be responsible for the oxidation of androstenol to androstenone and it could account for the fact that, while the boar maxillary gland smells most strongly of the alcohol, the saliva, breath and fat smell most strongly of the ketone (Patterson, 1968). The function of hydroxysteroid dehydrogenases in the maxillary glands of females, castrates and young pigs is unexplained though it seems possible they form part of a mechanism whereby internal changes in sex hormone status are expressed as an external olfactory signal.

I am very happy to thank Miss Christine Collings and Mrs Jill Clement for their excellent technical assistance and Dr R. L. S. Patterson and Mr C. A. Voyle of the Meat Research Institute, Langford, for their valuable help and advice.

\section{REFERENCES}

Baillie, A. H., Ferguson, M. M. \& HART, D. McK.(1966) Developments in steroid histochemistry. Academic Press, London and New York.

Claus, R., Hoffmann, B. \& Karg, H. (1971) Determination of 5-androst-16-en-3-one, a boar taint steroid in pigs, with reference to relationships to testosterone. F. Anim. Sci. 33, 1293.

Ferguson, M. M., Glen, J. B. \& Mason, D. K. (1970) Cortisol utilization by salivary gland, kidney and adrenal cortex. F. Endocr. 47, 511 .

Gower, D. B., Harrison, F. A. \& Heap, R. B. (1970) The identification of $\mathrm{C}_{19}$-16-unsaturated steroids and estimation of 17-oxosteroids in boar spermatic vein plasma and urine. F. Endocr. $47,357$.

KATKov, T. \& Gower, D. B. (1969) The biosynthesis of $3 \beta$-hydroxyandrosta-5, 16-diene and its further metabolism in the boar testis. Biochem. F. 115, 16P.

Melrose, R. D., Reed, H. C. B. \& Patterson, R. L. S. (1971) Androgen steroids associated with boar odour as an aid to the detection of oestrus in pig artificial insemination. Br. vet. F. 127, 497.

Patterson, R. L. S. (1968) Identification of $3 \alpha$-hydroxy-5 $\alpha$-androst-16-ene as the musk odour component of boar submaxillary salivary gland and its relationship to the sex odour taint in pork meat. J. Sci. Fd Agric. 19, 434. 